\title{
Purchase Intention on Embroidery Business: Why Perceived Packaging Doesn't Matter?
}

\author{
Ratni Prima Lita ${ }^{1}$, Meuthia Meuthia $^{2}$, Devi Yulia Rahmi ${ }^{3}$, Debi Syhtia Dewi ${ }^{4}$ \\ \{ratniprimalita@eb.unand.ac.id ${ }^{1}$, meuthia@eb.unand.ac.id², deviyuliarahmi@eb.unand.ac.id², \\ debishintyadewi@yahoo.co.id ${ }^{4}$ \} \\ Economics, Universitas Andalas, Indonesia ${ }^{1,2,3,4}$
}

\begin{abstract}
The research aimed to analyze the effect of perceived packaging on purchase intention, the effect of brand image on purchase intention, and the effect of WOM on purchase intention and brand image at Enni Design, an embroidery business in West Sumatera Indonesia. A quantitative approach and convenience sampling method were used. Meanwhile, the data analysis used a PLS-SEM. Our findings inclined that there was a positive and significant effect of brand image on purchase intention. Also, there was a positive and significant relationship between WOM and brand image and purchase intention. However, perceived packaging was proven to insignificantly affect purchase intention. Therefore, we suggest that Enni Design should give more concerns to and optimize its brand image, perceived packaging, and WOM to elevate consumers' or potential consumers' purchase intention.
\end{abstract}

Keywords: perceived packaging, brand image, WOM, purchase intention

\section{Introduction}

Creative industries are one of the most current preferred businesses. Creative industries are often referred to as the creative economy in Indonesia. The industries mainly rely on skills. The industries are expected to be a new national economic power in the future [1]. The argument is supported by the trend of creative economic contribution growth we acquired by the Indonesia Central Bureau of Statistics regarding the gross domestic product which increases annually. In 2015,2016 , and 2017, the trend growth was $7.39 \%, 7.44 \%$, and $7.57 \%$ respectively. One of the business units which offer handicraft product in West Sumatera Indonesia is Enni Design. Enni Design crafters also modify Kubang Weaving by adding kerancang, increasing the weaving's value. By its uniqueness, Enni Design is potential to create a distinctive brand image. To maintain its existence, Enni Design made various efforts; such as creating quality products. Quality products can give a good perception to consumers. The perception can increase an individual's purchase intention [2]. Besides, Enni Design consistently gives good packaging to affect customers' purchase intention. Packaging is one of the factors which distinguish a certain product from another competitive product [3]. Packaging is defined as an extrinsic element of a product [4]. According to [5], perceived packaging affects consumers' purchase intention. Furthermore, based on the research by [3], [6], the visual and functional elements of packaging can affect a product purchase. A brand image is brand perception given to consumers. According to [3], a brand implies durable and sustainable asset retailers use to distinguish their products. Meanwhile, a brand image implies a set of beliefs affecting the believers or non-believers while selecting a brand. It is line with the research by [7] who argue that there is a direct relationship between a brand image and purchase intention. Quality product packaging and good brand 
image need support from consumers' WOM behaviors to promote their purchase intention. WOM is one of the media to make a product recognizable. It spreads information more effectively. Enni Design's current designs include a sheet of plastic and paper bags decorated with a logo, descriptive picture, and address of Enni Design. With its good packaging and quality product, Enni Design expects an elevated sales value. However, based on our preliminary survey (2019), we found that people had a low interest in buying both hand-made and machine embroidery handicrafts.

\section{Literature Review}

\subsection{Impact of Perceived Packaging on Purchase Intention}

Packaging is the extrinsic element of a product [8]. [4] argue that packaging is an attribute which relates to a product but not the part of the physical element of the product. [9] believe that any corporate must spend money considerably to attract consumers. It must also create a good design in its product packaging. In the last decade, the concern on packaging in a marketing domain has been increasing. People found that packaging affected consumers' purchase decisions. Besides, packaging is one of the distinctive factors of a product [3]. Simply defined, packaging is the extrinsic element of a product [4]. Furthermore, a package is the container of a product. The key to making a good packaging design is that the packaging must be simple, functional, and trigger emotional positive responses. Packaging should be visually, emotionally, and rationally interesting because it can make a product more valuable. Besides, the visual and functional aspects of packaging also impact product purchasing, so perceived packaging significantly affects consumers' purchase intention [3], [6], [5]. Based on the elaboration above, the first hypothesis is: H1: There is a positive and significant relationship between perceived packaging and purchase intention.

\subsection{Impact of Brand Image and Purchase Intention}

A brand image is a consumers' perceived brand they use to distinguish between two corporates. Besides, a brand is long-lasting and sustainable asset retailers use to specify their products [3]. It is a set of beliefs which affect the owners while choosing a brand. It is in line with the finding of research by [7] which argues that there is a direct relationship between a brand image and purchase intention. Through a perception, consumers can make decisions about what products they are intending to buy. In other words, as perception is crucial, corporates should make strategies to sell their products and brand to give a good product perception. Therefore, a brand image significantly affects a purchase intention [10], [3]. Based on the elaboration above, the second hypothesis is: H2: There is a positive and significant relationship between brand image and purchase intention.

\subsection{The Relationship among WOM, Brand Image, and Purchase Intention}

The role of brand image is significant during the process of purchase decision making. A brand can give positive information which later affects quality, perceived value, and consumers' purchase intention. Consumers prefer to buy a popular brand with a positive brand image [10]. It is in line with [11] that theoretically, it is important to understand the unprofitable impacts of a perceived brand on attitude change/shaping. Word of Mouth (WOM) takes a significant role in consumers' decision-making processes. However, the effect of WOM depends on the product and reliance on WOM communication [12]. Besides, Word of Mouth (WOM), as clarified in any research, is a vital factor which contributes to consumers' decision making. Meanwhile, 
WOM is the main factor in consumers' behaviors. Several previous research has concluded that WOM is seven times more effective than advertisements in newspapers or magazines [13]. Moreover, positive WOM will be advantageous when producers are building a high-quality relationship with consumers [14]. If such a relationship has been built, a good brand image will emerge subsequently. Meanwhile, a brand image denotes all consumers' consumption experiences about certain goods or services [15]. A strong brand will promote consumers' trust while they are purchasing a product or service. Also, it enables them to describe any unseen factors better. Therefore, WOM significantly affects a purchase intention [16] and brand image [15]. Based on the elaboration above, the third and fourth hypotheses are: H3: There is a positive and significant relationship between WOM dan purchase intentions, and H4: There is a positive and significant relationship between WOM and brand image.

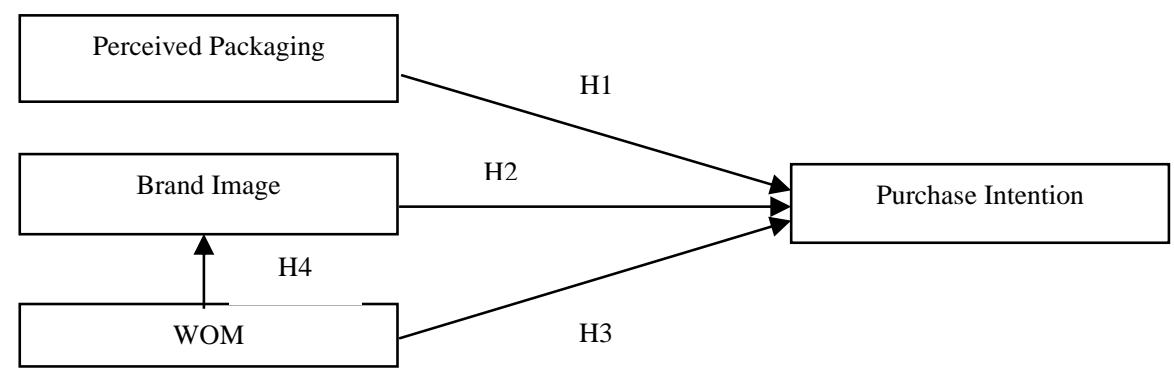

Fig. 1. Research Model Source: [5], [17], and [18]

\section{$3 \quad$ Methodology and Data Analysis}

The research was explanatory research with a quantitative approach. The data were primary data or data directly collected from 100 respondents [19] with a time horizon crosssectional in 2018. The data collection technique was a questionnaire, so we proposed some oral or written questions to respondents [19]. The answers to the questions were based on a Likert scale which was 1 to 5 (strongly disagree to strongly agree). Furthermore, the research units were individuals who had or had never made a transaction but been familiar with Enni Design. A convenience sampling method was used to take the sample [19]. Meanwhile, the minimum size of the sample was determined by multiplying the number of indicators by 5-10 [20]. We acquired 20 indicators which were the total number of variable indicators, so the sample consisted of 100 respondents (20 multiplied by 5). We conducted reliability testing using an output composite reliability as a standard. [21] convey that reliability testing is to indicate the consistency, accuracy, and precision of a measurement tool. Furthermore, [22] insist that the value of a variable has to be above 0.6 as the requirement of internal consistency size in composite reliability. A variable is reliable if it has a value of more than 0.6 after measured. Therefore, if the value is smaller than 0.6 , it is considered not reliable. We used item from [10] to measured of purchase intention. With get 0.85 composite reliability. Also, perceived packaging was measured using [5] the composite reliability was 1 . For brand image we used [17], composite reliability 0.88. And the last WOM adapted from [18] (composite reliability 1). This data was analysis using PLS-SEM. 


\section{Result and Discussion}

\subsection{Characteristics of Respondents}

The most respondents were women (93\%) and D3 graduates (62\%). Customers' purchase intention on Enni Design products was supported by their income which was mostly IDR $4,000,001$ - IDR 6,000,000 and their occupations in which most of them worked as private employees (47\%). Almost all respondents had bought embroidery products from Enni Design, implying their knowledge of the quality of Enni Design products. Also, it was proven by the frequency of purchase which was more than three times $(47 \%)$.

\subsection{Testing the Measurement Model (Outer Model)}

The average variance extracted (AVE) and outer loading were used as standards to measure convergent validity [23]. Convergent validity was identified to investigate whether indicators measured the research variables. According to [22], a variable was considered convergently valid if achieving an AVE value of more than 0.5 and an outer loading of more than 0.7. As indicated in Table 1, six indicators were deleted after two-time processing and hence we got all indicators valid. Measuring discriminant validity was to observe the correlation between a variable indicator score and its variable and compare the result with another variable. If the indicator score's correlation with its variable was stronger than that with another variable, the indicator was valid. Meanwhile, if the correlation was weaker, the indicator was invalid so the model compatibility should be reconsidered [22]. Discriminant validity was based on the output of cross-loading and latent variable correlations. All indicators in Table 1 had a stronger correlation with their variables than with another variable, hence all indicators were valid. Besides cross-loading, a discriminant validity test could also be observed from output latent variable correlations. According to [22], the square root of the AVE of each variable should be higher than the correlation with another variable in which the value in the diagonal line was acquired from each square root of the AVE of a variable ( $\sqrt{A V E}$ ). As inclined in Table 2, the $\sqrt{A V E}$ value of each variable was higher than other correlation values in the variable correlation matrix, and thus all variables were stated as discriminantly valid.

Table 1. Convergent and Discriminant Validity

\begin{tabular}{lcccccc}
\hline & $\begin{array}{c}\text { Brand } \\
\text { Image }\end{array}$ & $\begin{array}{c}\text { Perceived } \\
\text { Packaging }\end{array}$ & $\begin{array}{c}\text { Purchase } \\
\text { Intention }\end{array}$ & WOM & $\begin{array}{c}\text { Outer } \\
\text { Loading }\end{array}$ & AVE \\
\hline BI1 & 0.87166 & 0.180069 & 0.423953 & 0.407729 & 0.87166 & \\
BI2 & 0.88185 & 0.21138 & 0.369938 & 0.338691 & 0.88185 & 0.66889 \\
BI4 & 0.76368 & 0.005423 & 0.370964 & 0.287585 & 0.76368 & \\
BI5 & 0.74492 & 0.197229 & 0.308087 & 0.388795 & 0.74492 & 0.66588 \\
PI3 & 0.435326 & 0.24318 & 0.74196 & 0.340832 & 0.74196 & \\
PI4 & 0.256333 & 0.147038 & 0.83137 & 0.460167 & 0.83137 & 1 \\
PI5 & 0.403527 & 0.254682 & 0.86946 & 0.397234 & 0.86946 & 1 \\
PP3 & 0.185646 & 1 & 0.267045 & 0.16684 & 1 & 1 \\
WOM1 & 0.438163 & 0.16684 & 0.488111 & 1 & 1 & 1 \\
\hline
\end{tabular}

Source: Primary data processed using SmartPLS (2020)

Tabel 2. Discriminant Validity-Latent Variable Correlations

\begin{tabular}{lcccc}
\hline & Brand Image & Perceived Packaging & Purchase Intention & WOM \\
\hline Brand Image & 0.817857 & & & \\
Perceived Packaging & 0.185646 & 1 & & \\
Purchase Intention & 0.452723 & 0.267045 & 0.816015 & \\
\hline
\end{tabular}




\begin{tabular}{|c|c|c|c|c|}
\hline WOM & 0.438163 & 0.16684 & 0.488111 & 1 \\
\hline
\end{tabular}

\subsection{Testing the Structural Model (Inner Model)}

We used SmartPLS verse 2.0 M3 to process the research data. We evaluated the prediction ability of the model by examining the R Square output before testing the hypotheses. The R Square value would explain the degree of cross-variable impact. The R Square values of brand image and purchase intention variables were 0.191987 and 0.333121 respectively. Here, we could assume that brand image could be described by WOM by $19.19 \%$ and purchase intention could be described by perceived packaging, brand image, and WOM by $33.31 \%$. Moreover, the rest was described by other factors which were not the concern of this study. [25] declared that the standard R Square values of variables which were 0.67, 0.33, and 0.19 had substantial, moderate, and weak effects respectively. Referring to the previous explanation, the brand image variable had a weak effect and the purchase intention variable had a moderate effect.The last step consisted of hypothesis testing or a significance test using an output path coefficient as a standard. A hypothesis was considered significant if the t-statistic value was higher than the ttable value. A one-tailed hypothesis with a significance level of $0.05(\alpha=5 \%)$ was used and a t-table value of 1.664 was resulted. The result of the hypothesis test is presented in Table 3 .

Tabel 3. Structural Model Testing (Hypothesis)

\begin{tabular}{lllc}
\hline & Original Sample $(\mathbf{O})$ & T Statistics $(\mid \mathbf{O} /$ STERR|) & Description \\
\hline $\begin{array}{l}\text { H1.Perceived Packaging -> } \\
\text { Purchase Intention }\end{array}$ & 0.15927 & 1.658612 & Rejected \\
$\begin{array}{l}\text { H2.Brand Image -> Purchase } \\
\text { Intention }\end{array}$ & 0.273418 & 3.003571 & Accepted \\
$\begin{array}{l}\text { H3.WOM -> Purchase } \\
\text { Intention }\end{array}$ & 0.341737 & 3.826547 & Accepted \\
H4.WOM -> Brand Image & 0.438163 & 3.487147 & Accepted \\
\hline
\end{tabular}

Source: Primary data processed using SmartPLS (2020)

Three of four hypotheses i.e. a brand image positively and significantly affects purchase intention (H2) and WOM positively and significantly affects purchase intention and brand image (H3 and H4) were accepted. However, one hypothesis (H1) which was rejected perceived packaging toward purchase intention.Table 3 shows that perceived packaging did not affect purchase intention. It can be seen from the t-count value (1.658612) smaller than the t-table value (1.66). While purchasing, our respondents admitted that they did not put much consideration on the packaging of hand-made embroidery and machine embroidery products from Enni Design. Most of them thought that package was only a contemporary container of a product. As a result, they only needed it when shopping and threw it after using it. Based on the response, we found that packaging did not affect customers' purchase intention. It is not in line with the finding of research by [3], and [6]. The packaging is not significant because it is a unique Minangkabau handicraft product. consumers are interested in buying it not because the packaging is attractive but because of its uniqueness and the essential factor. Brand image positively and significantly affected purchase intention, indicated by the t- value (3.003571) which was higher than the t-table value (1.66). Persistently using the kerancang design which was a distinct design feature of Bukittinggi, Enni Design contributed to cultural preservation. It gave a perceived value to Enni Design and attracted respondents to purchase the products, even our respondents. This proved that the brand image of Enni Design could affect costumers' purchase intention. It is in line with the finding of research conducted by [10] arguing that 
consumers preferred to buy products from recognizable brands which had a positive brand image. Meanwhile, WOM positively and significantly impacted purchase intention, clarified by the t-count value higher than the t-table. Furthermore, it positively affected the purchase intention in hand-made and machine embroidery of Enni Design in Bukittinggi. The finding was in line with our survey in which we found that most Enni Design consumers were recommended to buy the products by family or partners. The recommendations, given by close people, ensured them to purchase products from Enni Design. The finding is in line with the finding of research by [16]. Besides, WOM also positively and significantly affected the brand image. It made Enni Design more recognizable, bettering its brand image. In addition to WOM, Enni Design had participated in both national and international fashion events to promote its brand. It is in line with the finding of research by [15]. According to them, WOM could positively and significantly affect brand image.

\section{Summary}

The research aimed to analyze the effect of perceived packaging, brand image, WOM, and purchase intention, the effect of brand image on the hand-made and machine embroidery products from Enni Design. We concluded that there was a positive and significant relationship between brand image and purchase intention $(\mathrm{H} 2)$ and between WOM and purchase intention and brand image (H3 and $\mathrm{H} 4)$. However, perceived packaging did not significantly affect purchase intention, so H1 was rejected.

\section{Implication/ Limitations and Suggestons For Further Research}

Based on the findings, we recommend Enni Design to reconsider and optimize its brand image, perceived packaging, and WOM to improve customers' purchase intention. Meanwhile, the result of this research can be developed as a product marketing strategy. Moreover, based on our survey result, several customers recommended Enni Design to improve its current packaging, motivating a higher purchase intention. Besides, Enni Design should promote its brand image. They can participate in more fashion events, either national or international ones. Moreover, the research is limited at the variables used which were brand image, WOM, perceived packaging, and purchase intention. Therefore, we recommend future researchers to use other variables to acquire more information about Enni Design.

\section{Acknowledgement}

This research was funded by Directorate of Research and Community Service Deputy for the Strengthening and Development of the Ministry of Research and Technology/ National Research and Innovation Agency in accordance with the Contract for Implementation of Community Service Programs with Contract Number T/36/UN.16.17?PT.01.03/PT-Sosial Humaniora/2020, March $10^{\text {th }} 2020$

\section{Reference}

[1] Rukmi, H. S., Fitria, L., \& Zonda, F. (2012). Studi Tentang Kondisi Industri Kreatif Permainan Interaktif di Kota Bandung Berdasarkan Faktor-Faktor yang Dipersepsikan Penting oleh Produsen dan Konsumennya, XVI(1), 67-76.

[2] Tsiotsou, R. (2006). The role of perceived product quality and overall satisfaction on purchase intentions, (March), 207-217. 
[3] Baskaran, S., Ayob, S. A., Howe, N. C., \& Mahadi, N. (2017). Understanding Purchase Intention of Ready-to-Eat Food among Malaysian Urbanites : A Proposed Framework, 7(11), 566-579.

[4] Deliya, M. M., \& Parmar, B. J. (2012). Role of Packaging on Consumer Buying BehaviorPatan District, 12(10).

[5] Kar, P., Meena, H. R., \& Patnaik, N. M. (2018). Factors Influencing Consumers Purchase Intention towards Organic and Cloned Animal Food Products, 7(1), 1-9.

[6] Mirabi, V., Akbariyeh, H., \& Tahmasebifard, H. (2015). A Study of Factors Affecting on Customers Purchase Intention Case Study: the Agencies of Bono Brand Tile in Tehran, 2(1), 267-273.

[7] Wang, Y., \& Tsai, C. (2014). The Relationship Between Brand Image and Purchase Intention: Evidence From Award Winning Mutual Funds. International Journal of Business \& Finance Research, 8(2), 27-40.

[8] Magnier, L., \& Schoormans, J. (2015). Consumer reactions to sustainable packaging: The interplay of visual appearance, verbal claim and environmental concern. Journal of Environmental Psychology, 44, 53-62.

[9] Bhakar, S., Bhakar, S., \& Dubey, A. (2015). Analysis of the factors affecting customers' purchase intention: The mediating role of customer knowledge and perceived value. Advances in Social Sciences Research Journal, 2(1), 87-101.

[10] Wu, S., \& Chang, H. (2016). The Model of Relationship between the Perceived Values and the Purchase Behaviors toward Innovative Products, 7(2), 31-45.

[11] Homer, P. M. (2008). Perceived quality and image: When all is not "rosy." Journal of Business Research, 61(7), 715-723.

[12] Bhayani, A. (2016). Word of mouth in consumers purchase decisions :The moderating role of product type,1-13.

[13] Murtiasih, S., \& Siringoringo, H. (2013). How Word of Mouth Influence Brand Equity for Automotive Products in Indonesia. Procedia - Social and Behavioral Sciences, 81, 40-44.

[14] Tho, N. D., Thi, N., Trang, M., \& Olsen, S. O. (2016). Brand personality appeal , brand relationship quality and WOM transmission : a study of consumer markets in Vietnam. Asia Pacific Business Review, 2381, 1-18.

[15] Jalilvand, M. R., Esfahani, S. S., \& Samiei, N. (2011). Electronic word-of-mouth: Challenges and opportunities. Procedia Computer Science, 3, 42-46.

[16] Rubamak, M.D., \& Rahayu, B. (2017). Pengaruh Word of Mouth terhadap purchase intention melalui brand image pada lembaga kurusu bahasa Inggris dynamic english course Pare. Jurnal Ekonomi Universitas Kediri.

[17] Hanaysha, J. (2016). The Importance of Product Innovation in Driving Brand Success : An Empirical Study on Automotive Industry. American Journal of Economics and Business Administration, 8(1), 35-43.

[18] Casidy, R., \& Wymer, W. (2016). Linking prestige perception with consumption experience, loyalty, and WOM. Marketing Intelligence \& Planning, 34(4), 540-558.

[19] Sekaran, U., \& Bougie, R. (2011). Business Research Methods: A skill-building approach. New York: McGraw-Hill.

[20] Hair, J. F., Ringle, C. M., \& Sarstedt, M. (2011). PLS-SEM: Indeed a silver bullet. Journal of Marketing Theory and Practice, 19(2), 139-152.

[21] Jogiyanto, H. M., \& Abdillah, W. (2009). Konsep dan aplikasi PLS (Partial Least Square) untuk penelitian empiris. BPFE Fakultas Ekonomika Dan Bisnis UGM. Yogyakarta.

[22] Hair Jr, J. F., Hult, G. T. M., Ringle, C., \& Sarstedt, M. (2016). A primer on partial least squares structural equation modeling (PLS-SEM). Sage Publications. 